\title{
Insecticide susceptibility of Aedes aegypti and Aedes albopictus in Central Africa
}

\author{
Basile Kamgang ${ }^{1,2}$, Sébastien Marcombe ${ }^{1}$, Fabrice Chandre', Elysée Nchoutpouen ${ }^{1,2}$, Philippe Nwane², \\ Josiane Etang ${ }^{2}$, Vincent Corbel ${ }^{1,3}$ and Christophe Paupy ${ }^{1,4^{*}}$
}

\begin{abstract}
Background: Aedes aegypti (Linnaeus, 1762) and Aedes albopictus (Skuse, 1894) are the main vectors of dengue (DENV) and chikungunya (CHIKV) viruses worldwide. As there is still no vaccine or specific treatment for DENV and $\mathrm{CHIKV}$, vector control remains the cornerstone of prevention and outbreak control. Unfortunately, vector control programs are facing operational challenges with mosquitoes becoming resistant to commonly used insecticides in several areas through the world. Throughout Central Africa no recent data are available susceptible/resistant status of either vector species since the introduction/arrival of Ae. albopictus in this area. We therefore studied the level of resistance of these two major vectors to insecticides commonly used in Africa for mosquito control.
\end{abstract}

Results: Aedes aegypti and Ae. albopictus were sampled in six urban localities of Cameroon (Garoua, Bertoua, Yaoundé, Bafia, Buea) and Gabon (Libreville). Larval bioassays, carried out to determine the lethal concentrations $\left(L C_{50}\right.$ and $\left.L C_{95}\right)$ and resistance ratios $\left(R R_{50}\right.$ and $\left.R R_{95}\right)$ suggested that both vector species were susceptible to $B t i$ (Bacillus thuringiensis var israeliensis) and temephos. Bioassays were also performed on adults using WHO diagnostic test kits to assess phenotypic resistance to deltamethrin, DDT, fenitrothion and propoxur. These experiments showed that one population of Ae. aegypti (Libreville) and two populations of Ae. albopictus (Buea and Yaoundé) were resistant to DDT (mortality 36\% to 71\%). Resistance to deltamethrin was also suspected in Ae. albopictus from Yaoundé (83\% mortality). All other field mosquito populations were susceptible to deltamethrin, DDT, fenitrothion and propoxur. No increase in the knockdown times $\left(\mathrm{Kdt}_{50}\right.$ and $\left.\mathrm{Kdt}_{95}\right)$ was noted in the Yaoundé resistant population compared to other Ae. albopictus populations, suggesting the possible involvement of metabolic resistance to deltamethrin and DDT.

Conclusion: In view of the recent increase in dengue and chikungunya outbreaks in Central Africa, these unique comparative data on the insecticide susceptibility of Ae. aegypti and Ae. albopictus could help public health services to design more effective vector control measures.

\section{Background}

Dengue virus (DENV, Flaviviridae, Flavivirus) and chikungunya virus (CHIKV, Togaviridae, Alphavirus) are mosquito-borne viruses of medical concern in most tropical regions. With about 50-100 million reported cases annually, including 500000 severe cases of dengue haemorrhagic fever (DHF) or dengue shock syndrome (DSS), DENV is the most prevalent mosquito-borne human virus worldwide [1]. In West and Central Africa, where DENV epidemics remained limited until 5 years ago, the

\footnotetext{
* Correspondence: christophe.paupy@ird.fr

'Institut de Recherche pour le Développement (IRD), UMR 224 MIVEGEC, BP 64501, 34394 Montpellier, France

Full list of author information is available at the end of the article
}

number of outbreaks or case reports has increased significantly in several areas, including Cameroon in 2006 [2,3], Gabon in 2007 [4], and West African countries such as Mali in 2008, and Cape Verde and Senegal in 2009 [5]. Similarly, CHIKV, which previously caused only sporadic outbreaks in sub-Saharan Africa [6], has recently emerged in several urban epidemic foci in Central Africa [4].

Aedes aegypti (Linnaeus, 1762) and Aedes albopictus (Skuse, 1894) are the main epidemic vectors of DENV and CHIKV worldwide [2,7]. Both species occur in subSaharan Africa: Ae aegypti is native to Africa and Ae. albopictus has recently invaded several Central African countries [8]. Recent observations in Cameroon [9] and

\section{Biomed Central}


Gabon [10] indicate that these two species infest urban environments.

As there is still no vaccine or specific treatment for DENV or CHIKV, vector control remains the cornerstone of prevention and outbreak control. Conventional control strategies rely on the reduction of larval sources by eradicating water-holding containers that serve as larval habitats, and by using larvicides (e.g. temephos and Bacillus thuringiensis var israeliensis [Bti]) in natural and/or domestic breeding sites [11]. Space spraying (using pyrethroids or organophosphates) is generally used when larval source reduction fails to reduce the density of adult mosquitoes, and also during outbreak situations [12]. Unfortunately, many vector control programs are threatened by the development of insecticide resistance in Ae. aegypti and Ae. albopictus [13-16]. Resistance to multiple insecticides (e.g. pyrethroids and organophosphates) has been reported in Ae. aegypti in South-East Asia $[17,18]$, South America and the Caribbean [19-21]. There have been fewer reports of insecticide resistance in Ae. albopictus [15,22], although a significant decrease in susceptibility to permethrin, malathion and temephos has been observed in Thailand [14]. In West and Central Africa, most available data on pesticide resistance concern Ae. aegypti but date back more than 30-40 years [23], while virtually no such data are available for Ae. albopictus, owing to its recent introduction in Africa. In order to implement effective and sustainable arbovirus vector control measures, there is an urgent need to determine the susceptibility of the two major vectors of DENV and CHIK to insecticides commonly used for mosquito control. We therefore examined the distribution and insecticide susceptibility of both larval and adult Ae. aegypti and Ae. albopictus populations in sentinel sites from Central Africa (Cameroon and Gabon) using WHOPES-approved procedures $[24,25]$.

\section{Materials and methods Mosquito sampling}

Aedes aegypti and Ae. albopictus mosquitoes were sampled as larvae or pupae in six urban localities (Figure 1): Garoua $\left(09^{\circ} 16^{\prime} \mathrm{N} ; 13^{\circ} 25^{\prime} \mathrm{E}\right)$, Bertoua $\left(04^{\circ} 33^{\prime} \mathrm{N} ; 13^{\circ} 46^{\prime} \mathrm{E}\right)$, Yaoundé $\left(03^{\circ} 54^{\prime} \mathrm{N} ; 12^{\circ} 29^{\prime} \mathrm{E}\right)$, Bafia $\left(04^{\circ} 44^{\prime} \mathrm{N} ; 11^{\circ} 11^{\prime} \mathrm{E}\right)$ and Buea $\left(04^{\circ}\right.$ $09^{\prime} \mathrm{N}$; $09^{\circ} 13^{\prime} \mathrm{E}^{\circ}$ ) in Cameroon in April 2007, and Libreville, Gabon $\left(00^{\circ} 23^{\prime} \mathrm{N} ; 09^{\circ} 27^{\prime} \mathrm{E}\right)$ in June 2007 . An additional $A e$. aegypti population (Bénoué) was sampled in the Bénoué National Park $\left(08^{\circ} 15^{\prime} \mathrm{N} ; 13^{\circ} 49^{\prime} \mathrm{E}\right)$. The latter population, which is sylvan and thus considered as naïve to pesticide, was used as a susceptible reference strain. Immature stages (field generation, F0) were collected from water in domestic (e.g. jars, tanks), peri-domestic (e.g. tires) and natural environments (e.g. tree holes). For each sampling site, larvae or pupae from 2-6 larval breeding places were collected, stored in plastic boxes and transferred to insectaries for rearing to the adult stage. Once identified as $A e$. aegypti or Ae. albopictus, mosquitoes of the same species and from the same locality were pooled to prevent inbreeding. Mosquitoes were reared to generation F1 for larval and adult bioassays. Mosquito populations were maintained at insectaries conditions $\left(27^{\circ} \mathrm{C}+/-2^{\circ} \mathrm{C}\right.$; relative humidity $80 \%+/-10 \%$ ) and females were fed on rabbits to complete their gonotrophic cycle.

\section{Larval bioassay}

The susceptibility of larvae to temephos (organophosphate, Sigma Aldrich-Pestanal, Seelze, Germany) and Bti (VectoBac, Bayer CropScience, Monheim, Germany) was assessed using standard WHO bioassays [24]. Stock solutions and serial dilutions were prepared in 95\% ethanol (temephos) or mineral water $(B t i)$ and were stored at $+4^{\circ} \mathrm{C}$. Each bioassay used 25 late-third or early-fourth instars in plastic cups with $99 \mathrm{ml}$ of mineral water and $1 \mathrm{ml}$ insecticide solution at the required concentration. We used 5 concentrations in the range of activity of each insecticide and 50 to 100 larvae per concentration (with two to four replicates, depending on the sample and the number of larvae available). Each bioassay included a control group which received $1 \mathrm{~mL}$ of ethanol (for temephos) or $1 \mathrm{~mL}$ of mineral water (for $B t i$ ) only. Tests were run at $27^{\circ} \mathrm{C} \pm 2{ }^{\circ} \mathrm{C}$, and mortality was assessed after $24 \mathrm{~h}$ of insecticide exposure. For each mosquito strain, one replicate corresponded to a single rearing batch.

\section{Adult bioassay}

The procedure used for adult bioassays followed the standard WHO protocol [25]. Papers were impregnated using acetone solutions of insecticide and silicone oil as the carrier at the "Laboratoire de Lutte contre les Insectes Nuisibles" (LIN), Montpellier, France (WHO Collaborating Centre) using diagnostic concentrations defined for Aedes laboratory strain (Bora) susceptible reference strain [17]. Four technical-grade compounds representing the 4 major classes of insecticide (carbamate, organochlorine, pyrethroid and organophosphate) were used as follows: $0.3 \%$ propoxur (Bayer CropScience, Monheim, Germany), 4\% DDT (Hindustan Insecticides Limited, New Delhi, India), 0.06\% deltamethrin (Agrevo Environmental Health, Berkhamsted UK) and 0.5\% fenitrothion (SUPELCO, Bellefonte, USA). Two to four batches of 25 non-blood-fed females (2-4 days of age) were introduced into exposure tubes containing impregnated filter papers for 60 minutes. The number of knocked-down (Kd) mosquitoes was recorded every 5 minutes. The mosquitoes were then transferred to a recovery tube containing $10 \%$ glucose solution and maintained at $27^{\circ} \mathrm{C} \pm 2{ }^{\circ} \mathrm{C}$ with $80 \% \pm 10 \%$ relative humidity. Mortality was recorded 24 hours post-exposure. 


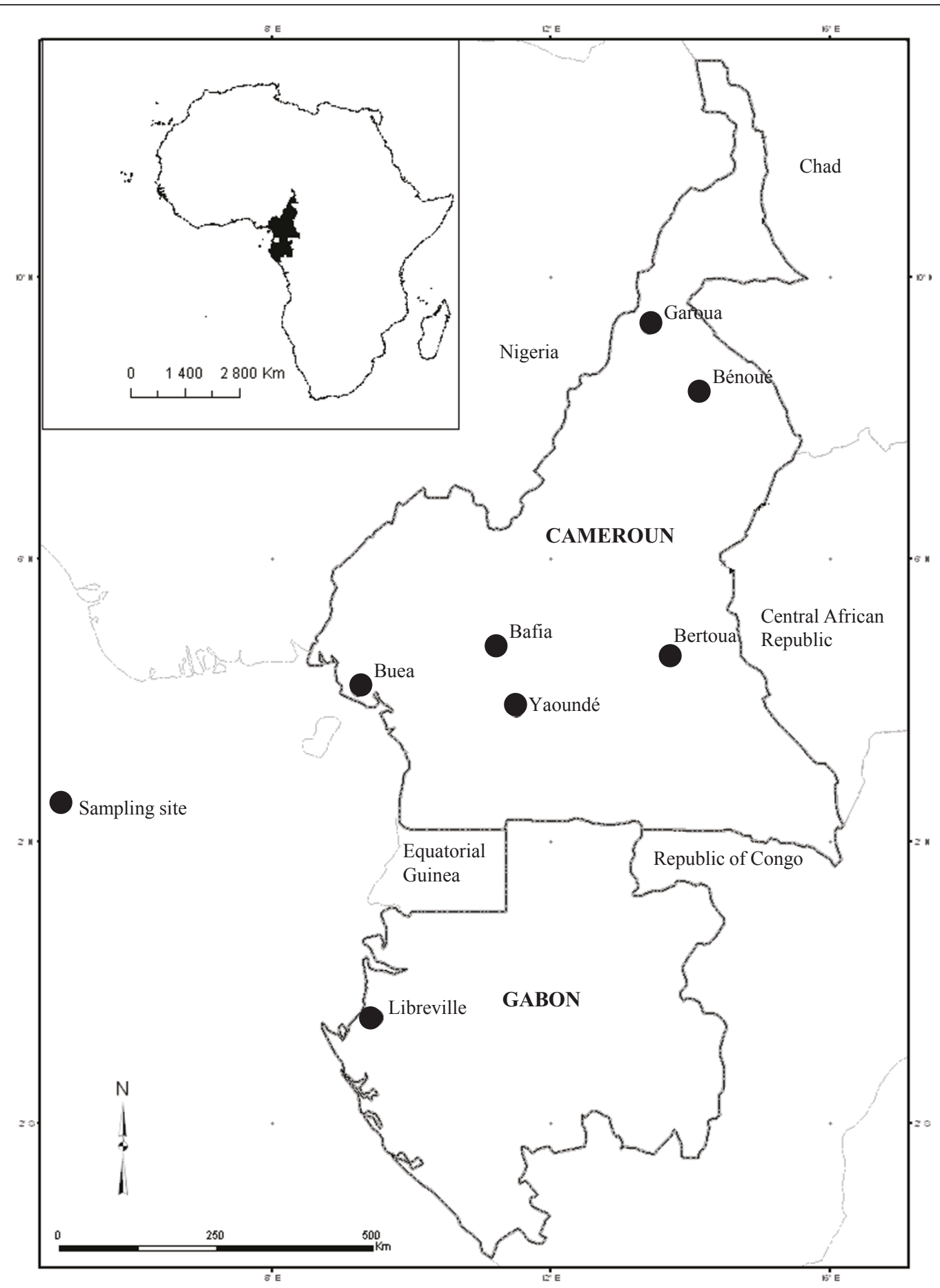

Figure 1 Aedes aegypti and Ae. albopictus sampling sites in Cameroon and Gabon.

For each strain a batch of 25 mosquitoes was used as control.

\section{Data analysis}

Larval and adult mortality rates were corrected using Abbott's formula (Abbott 1925) in case of control mortality $>5 \%$ but less than $20 \%$. Data from larval bioassays were analyzed with Win DL 2.0 software [26], which uses the iterative method of maximum likelihood to fit a linear regression between the log of the insecticide concentration and the probit of mortality. Goodness-of-fit was estimated with the Pearson $\chi^{2}$ test. Win DL 2.0 
provided also the slope of the regression lines and the estimates of lethal concentrations ( $\mathrm{LC}_{50}$ and $\mathrm{LC}_{95}$ ) with their 95\% confidence intervals (CI). Resistance ratios $\left(\mathrm{RR}_{50}\right.$ and $\mathrm{RR}_{95}$ ) of each population compared to the Bénoué strain of Ae. aegypti (used as reference) were calculated as follows: $\mathrm{RR}_{50}=\mathrm{LC}_{50}$ assay/ $\mathrm{LC}_{50}$ reference; $\mathrm{RR}_{95}=\mathrm{LC}_{95}$ assay $/ \mathrm{LC}_{95}$ reference. A mosquito population was considered susceptible when $R_{50}$ was less than 2 , potentially resistant when $R_{50}$ was between 2 and 5 , and resistant when $\mathrm{RR}_{50}$ was over 5 . For adult bioassays, resistant/susceptible status was defined according to WHO criteria [27]. Mosquitoes were considered susceptible if the mortality rates were greater than $97 \%$ and resistant if mortality rates were less than $80 \%$. Mortality rates between $80-97 \%$ suggested possible resistance.

For deltamethrin and DDT, the knockdown times (KdT50 and KdT95) and their 95\% confidence intervals were estimated with Win DL 2.0 software.

\section{Results}

\section{Larval bioassay}

Larval bioassays using Bti showed that $\mathrm{LC}_{50}$ and $\mathrm{LC}_{95}$ for Ae. albopictus ranged from $0.18 \mathrm{mg} / \mathrm{l}$ for the Bénoué strain (susceptible reference strain) to $0.69 \mathrm{mg} / \mathrm{L}$ for the Yaoundé and Buea populations. Against Ae. aegypti, Bti acted in a similar range of concentrations, with $\mathrm{LC}_{50}$ and $\mathrm{LC}_{95}$ ranging from $0.18 \mathrm{mg} / \mathrm{L}$ for Garoua to $0.91 \mathrm{mg} / \mathrm{L}$ for Bafia (Table 1). $\mathrm{RR}_{50}$ ranged from 1.00 (Garoua) to 1.50 (Bertoua) and $\mathrm{RR}_{95}$ from 1.13 (Libreville) to 2.84 (Bafia). These values and their 95\%CIs indicated that all Ae. aeggyti and Ae. albopictus populations were similarly susceptible to Bti.

Against Ae aegypti, bioassays showed that temephos $\mathrm{LC}_{50}$ values ranged from $0.004 \mathrm{mg} / \mathrm{L}$ (Garoua) to 0.009 $\mathrm{mg} / \mathrm{l}$ (Bertoua) and the $\mathrm{LC}_{95}$ from $0.006 \mathrm{mg} / \mathrm{L}$ (Garoua) to $0.026 \mathrm{mg} / \mathrm{L}$ (Bertoua) (Table 2). $\mathrm{RR}_{50}$ ranged from 0.75 (Garoua) to 1.75 (Bertoua) and $\mathrm{RR}_{95}$ from 0.66 (Garoua) to 2.68 (Bertoua). These findings suggested that all the mosquito samples tested were susceptible to temephos. Concerning the Bertoua sample, although the RR95 value was over 2 indicating a suspected resistance, the IC values did not confirm this trend. $\mathrm{LC}_{50}$ values for Ae. albopictus ranged from 0.005 (Bertoua) to $0.008 \mathrm{mg} / \mathrm{L}$ (Libreville) and $\mathrm{LC}_{95}$ values from 0.008 (Yaoundé) to $0.017 \mathrm{mg} / \mathrm{L}$ (Libreville). $\mathrm{RR}_{50}$ ranged from 0.92 (Bertoua) to $1.43 \mathrm{mg} / \mathrm{L}$ (Libreville) and $\mathrm{RR}_{95}$ from 0.82 (Yaoundé) to $1.75 \mathrm{mg} / \mathrm{L}$ (Libreville), indicating susceptibility of all the mosquito populations to temephos.

\section{Adult bioassay}

After $24 \mathrm{~h}$ post-exposure, one population of Ae. aegypti (Libreville) and two populations of Ae. albopictus (Buea and Yaoundé) were resistant to DDT (mortality 36\% to $71 \%)$. DDT mortality rates suggested probable resistance in the Garoua Ae. aegypti population (97\%) and the Bertoua Ae. albopictus population (80\%). Probable resistance to deltamethrin was also detected in the Yaoundé Ae. albopictus population (80\%). All Ae. aegypti except Yaoundé, and all Ae. albopictus populations were susceptible to deltamethrin, propoxur and fenitrothion (99-100\%) (Table 3).

The estimated knockdown times (KdT) for Ae. aegypti mosquitoes exposed to deltamethrin indicated that the $\mathrm{KdT}_{50}$ and $\mathrm{KdT}_{95}$ values of the field populations were similar (overlapping 95\%CIs) to those of the reference strain (Table 4). $\mathrm{KdT}_{50}$ values recorded in Yaoundé and Buea Ae. albopictus strains were higher than for the reference strain. Despite the ICs calculated for these two strains did not overlapped with the IC of the reference, the increase in $\mathrm{KdT}$ seemed no significant $(\mathrm{P}>$ or $=$ 0.05). The DDT $\mathrm{KdT}_{50}$ for all Ae. albopictus samples and the $\mathrm{KdT}_{95}$ for Ae. albopictus Bertoua were significantly higher than the corresponding values for all $A e$. aegypti samples. These differences in KdT between $A e$. aegypti and Ae. albopictus may be physiological and/or species-dependent.

\section{Discussion}

All Ae. aegypti and Ae. albopictus samples collected in Cameroon and Libreville (Gabon) were susceptible to $B t i$ and temephos. Resistance to Bti has been described in Culex pipiens in the USA [28] and suspected in Aedes rusticus in France [29], but no resistance to this pesticide has been reported to date in Ae aegypti or Ae. albopictus worldwide. Temephos is the most widely used larvicide for dengue vector control. Resistance to this organophosphate has been recorded in Ae. aegypti in Asia [30-34] and South America [35-37], and in Ae. albopictus in Malaysia [38] and Thailand [14]. Mouchet et al. [23] observed full susceptibility of Ae. aegypti larvae to temephos in Cameroon and Gabon (Libreville and Yaoundé) during the 1970s. Up to now, larvicides targeting these two species have rarely been used in African countries, thus explaining the persistent susceptibility to temephos and Bti in this part of the world.

WHO bioassays carried out on adult mosquitoes showed DDT resistance in one Ae aegypti population from Gabon (Libreville) and two Ae. albopictus populations from Cameroun (Buea and Yaoundé). In addition, DDT resistance was suspected in the Ae. albopictus sample from Bertoua. DDT resistance has been widely found in Ae aegypti worldwide, including in Cameroon [23]. $K d r$ mutation of the voltage-gated sodium channel has been found to confer resistance to DDT in Ae. aegypti [39] but detoxifying enzymes such as glutathione S-transferases (GSTs) can also play a key role in DDT metabolism and resistance [40]. Although DDT resistance has also been recorded in Ae. albopictus in Thailand and 
Table 1 Susceptibility of Ae. aegypti and Ae. albopictus larvae to Bti

\begin{tabular}{|c|c|c|c|c|c|c|c|}
\hline Sample & $N$ & Regression line & Pearson $\chi^{2}$ goodness of fit & $\begin{array}{c}\mathrm{LC}_{50} \\
(95 \% \mathrm{Cl})\end{array}$ & $\begin{array}{c}\mathrm{LC}_{95} \\
(95 \% \mathrm{Cl})\end{array}$ & $\mathrm{RR}_{50}$ & $\mathrm{RR}_{95}$ \\
\hline \multicolumn{8}{|l|}{ Ae. aegypti } \\
\hline Garoua & 493 & $Y=5.67 X+4.15$ & 0.69 & $\begin{array}{c}0.18 \\
(0.03-0.45)\end{array}$ & $\begin{array}{c}0.36 \\
(0.30-0.45)\end{array}$ & 1.00 & 1.13 \\
\hline Bertoua & 498 & $Y=3.84 X+2.13$ & 0.62 & $\begin{array}{c}0.27 \\
(0.19-0.39)\end{array}$ & $\begin{array}{c}0.75 \\
(0.20-2.77)\end{array}$ & 1.50 & 2.34 \\
\hline Yaoundé & 252 & $Y=8.77 X+5.76$ & 0.27 & $\begin{array}{c}0.22 \\
(0.20-0.44)\end{array}$ & $\begin{array}{c}0.34 \\
(0.26-0.44)\end{array}$ & 1.22 & 1.06 \\
\hline Bafia & 500 & $Y=2.99 X+1.75$ & 0.54 & $\begin{array}{c}0.25 \\
(0.21-0.31)\end{array}$ & $\begin{array}{c}0.91 \\
(0.17-4.89)\end{array}$ & 1.39 & 2.84 \\
\hline Libreville & 500 & $Y=6.06 X+4.28$ & 0.21 & $\begin{array}{c}0.19 \\
(0.09-0.24)\end{array}$ & $\begin{array}{c}0.36 \\
(0.32-0.46)\end{array}$ & 1.06 & 1.13 \\
\hline \multicolumn{8}{|l|}{ Ae. albopictus } \\
\hline Yaoundé & 500 & $Y=1.91 X-0.04$ & 0.64 & $\begin{array}{c}0.19 \\
(0.17-0.21)\end{array}$ & $\begin{array}{c}0.69 \\
(0.26-1.85)\end{array}$ & 1.05 & 1.06 \\
\hline Bertoua & 477 & $Y=16.31 X+9.32$ & 0.94 & $\begin{array}{c}0.27 \\
(0.25-0.28)\end{array}$ & $\begin{array}{c}0.34 \\
(0.32-0.40)\end{array}$ & 1.50 & 1.13 \\
\hline Buea & 375 & $Y=3.08 X+2.13$ & 0.51 & $\begin{array}{c}0.20 \\
(0.10-0.39)\end{array}$ & $\begin{array}{c}0.69 \\
(0.26-1.85)\end{array}$ & 1.11 & 1.06 \\
\hline Reference strain & 496 & $Y=7.04 X+5.11$ & 0.40 & $\begin{array}{c}0.18 \\
(0.11-0.22)\end{array}$ & $\begin{array}{c}0.32 \\
(0.29-0.36)\end{array}$ & & \\
\hline
\end{tabular}

$\mathrm{N}$ : Total number of mosquitoes assayed; $50 \%$ and $95 \%$ lethal concentrations, $\mathrm{LC}_{50}$ and $\mathrm{LC}_{95}$, are expressed in $\mathrm{mg} / \mathrm{liter} ; 95 \% \mathrm{Cl}: 95 \%$ confidence interval; $\mathrm{p}>0.05$ suggests a well-fitting model, $\mathrm{P}<0.05$ suggests an invalid model population.

Table 2 Susceptibility of Ae. aegypti and Ae. albopictus larvae to Temephos

\begin{tabular}{|c|c|c|c|c|c|c|c|}
\hline Sample & $\mathrm{N}$ & Regression line & Pearson $\chi^{2}$ goodness of fit & $\begin{array}{c}\mathrm{LC}_{50} \\
(95 \% \mathrm{Cl})\end{array}$ & $\begin{array}{c}\mathrm{LC}_{95} \\
(95 \% \mathrm{Cl})\end{array}$ & $\mathrm{RR}_{50}$ & $\mathrm{RR}_{95}$ \\
\hline \multicolumn{8}{|l|}{ Ae. aegypti } \\
\hline Garoua & 500 & $Y=10.68 X+25.82$ & 0.36 & $\begin{array}{c}0.0040 \\
(0.0037-0.0042)\end{array}$ & $\begin{array}{c}0.0064 \\
(0.0060-0.0070)\end{array}$ & 0.75 & 0.66 \\
\hline Bertoua & 500 & $Y=3.57 X+7.28$ & 0.48 & $\begin{array}{c}0.0090 \\
(0.0048-0.0170)\end{array}$ & $\begin{array}{c}0.0260 \\
(0.0022-0.3100)\end{array}$ & 1.75 & 2.68 \\
\hline Yaoundé & 253 & $Y=11.36 X+25.68$ & 0.30 & $\begin{array}{c}0.0055 \\
(0.0052-0.006)\end{array}$ & $\begin{array}{c}0.0076 \\
(0.0067-0.0100)\end{array}$ & 1.04 & 0.78 \\
\hline Bafia & 500 & $Y=7.07 X+16.04$ & 0.006 & $\begin{array}{c}0.0053 \\
(0.0047-0.0084)\end{array}$ & $\begin{array}{c}0.0092 \\
(0.0068-0.0410)\end{array}$ & 1.02 & 0.95 \\
\hline Libreville & 500 & $Y=8.17 X+19.56$ & 0.061 & $\begin{array}{c}0.0043 \\
(0.0020-0.0081)\end{array}$ & $\begin{array}{c}0.0068 \\
(0.0051-0.0080)\end{array}$ & 0.81 & 0.70 \\
\hline
\end{tabular}

\begin{tabular}{|c|c|c|c|c|c|c|c|}
\hline \multicolumn{8}{|l|}{ Ae. albopictus } \\
\hline Bertoua & 493 & $Y=6.75 X+15.58$ & 0.14 & $\begin{array}{c}0.0049 \\
(0.0013-0.0180)\end{array}$ & $\begin{array}{c}0.0086 \\
(0.0061-0.0120)\end{array}$ & 0.92 & 0.89 \\
\hline Yaoundé & 497 & $Y=8.00 X+18.38$ & 0.30 & $\begin{array}{c}0.0050 \\
(0.0021-0.0110)\end{array}$ & $\begin{array}{c}0.0080 \\
(0.0064-0.0100)\end{array}$ & 0.94 & 0.82 \\
\hline Buea & 375 & $Y=9.57 X+20.55$ & 0.27 & $\begin{array}{c}0.0071 \\
(0.0065-0.0200)\end{array}$ & $\begin{array}{c}0.012 \\
(0.0087-0.0500)\end{array}$ & 1.34 & 1.03 \\
\hline Libreville & 275 & $Y=4.56 X+25.68$ & 0.11 & $\begin{array}{c}0.0076 \\
(0.0023-0.0240)\end{array}$ & $\begin{array}{c}0.017 \\
(0.0017-0.1700)\end{array}$ & 1.43 & 1.75 \\
\hline Reference strain & 500 & $Y=6.22 X+14.17$ & 0.57 & $\begin{array}{c}0.0053 \\
(0.0035-0.0079)\end{array}$ & $\begin{array}{c}0.0097 \\
(0.0073-0.012)\end{array}$ & & \\
\hline
\end{tabular}

$\mathrm{N}$ : Total number of mosquitoes assayed; $50 \%$ and $95 \%$ lethal concentrations, $\mathrm{LC}_{50}$ and $\mathrm{LC}_{95}$, are expressed in $\mathrm{mg} / \mathrm{liter} ; 95 \% \mathrm{Cl}: 95 \%$ confidence interval; $\mathrm{p}>0.05$ suggests a well-fitting model, $\mathrm{P}<0.05$ suggests an invalid model population. 
Table 3 Aedes aegypti and Ae. albopictus mortality rates $24 \mathrm{~h}$ after exposure to insecticides at diagnostic doses

\begin{tabular}{|c|c|c|c|c|c|c|c|c|}
\hline & \multicolumn{8}{|c|}{ Mortality rate (\%) } \\
\hline & \multicolumn{2}{|c|}{$0.06 \%$ Deltamethrin } & \multicolumn{2}{|c|}{ 4\% DDT } & \multicolumn{2}{|c|}{ 0.3\% Propoxur } & \multicolumn{2}{|c|}{$0.5 \%$ Fenitrothion } \\
\hline & Assay & Control & Assay & Control & Assay & Control & Assay & Control \\
\hline \multicolumn{9}{|l|}{ Ae. aegypti } \\
\hline Garoua & $100(89)$ & $2(50)$ & $96.8(95)$ & $8(50)$ & $100(100)$ & $8(50)$ & $100(99)$ & $2(50)$ \\
\hline Bertoua & $100(100)$ & $2(50)$ & \multicolumn{2}{|c|}{-} & \multicolumn{2}{|c|}{ - } & $100(98)$ & $2(50)$ \\
\hline Yaoundé & 100 (95) & $4(50)$ & \multicolumn{2}{|c|}{-} & \multicolumn{2}{|c|}{ - } & $100(96)$ & $4(50)$ \\
\hline Bafia & $100(97)$ & $4(50)$ & \multicolumn{2}{|c|}{-} & \multicolumn{2}{|c|}{-} & $100(97)$ & $4(50)$ \\
\hline Libreville & $100(97)$ & $0(50)$ & 70.7 (99) & $0(50)$ & $99(100)$ & $0(50)$ & $100(99)$ & $0(50)$ \\
\hline \multicolumn{9}{|l|}{ Ae. albopictus } \\
\hline Bertoua & $100(80)$ & $0(50)$ & $80.5(87)$ & $8(50)$ & $100(94)$ & $8(50)$ & $100(61)$ & $0(50)$ \\
\hline Yaoundé & $83.3(96)$ & $2(50)$ & $36.3(91)$ & $12(50)$ & $100(96)$ & $12(50)$ & $100(98)$ & $2(50)$ \\
\hline Buea & $100(50)$ & $4(50)$ & $47.0(85)$ & $2(50)$ & $100(92)$ & $2(50)$ & $100(50)$ & $4(50)$ \\
\hline Reference strain & $100(96)$ & $2(50)$ & \multicolumn{2}{|c|}{-} & \multicolumn{2}{|c|}{-} & $100(100)$ & $2(50)$ \\
\hline
\end{tabular}

Numbers in brackets indicate the number of mosquitoes assayed; -: sample not assayed.

Japan $[41,42]$, the underlying mechanisms remain unclear.

This study also showed full susceptibility of $A e$. aegypti and Ae. albopictus to deltamethrin, except in Yaoundé where the Ae. albopictus population showed mortality rates of around $80 \%$, strongly suggesting resistance. Pyrethroid resistance in Ae. aegypti is widespread $[43,15]$ and is usually associated with an altered amino acid sequence of the target protein, the sodium channel that confers knockdown resistance when altered (the so-

Table 4 Knockdown times of Ae. aegypti and Ae. albopictus exposed to $0.06 \%$ deltamethrin and $4 \%$ DDT

\begin{tabular}{|c|c|c|c|c|}
\hline \multirow[t]{3}{*}{ Locality } & \multicolumn{2}{|c|}{ Ae. aegypti } & \multicolumn{2}{|c|}{ Ae. albopictus } \\
\hline & $\begin{array}{c}\mathrm{KdT}_{50} \\
(95 \% \mathrm{Cl}) ; \mathrm{P}^{*}\end{array}$ & $\begin{array}{c}\mathrm{KdT}_{95} \\
(95 \% \mathrm{Cl}) ; \mathrm{P}^{*}\end{array}$ & $\begin{array}{c}\mathrm{KdT}_{50} \\
(95 \% \mathrm{Cl}) ; \mathrm{P}^{*}\end{array}$ & $\begin{array}{c}\mathrm{KdT}_{95} \\
(95 \% \mathrm{Cl}) ; \mathrm{P}^{*}\end{array}$ \\
\hline & \multicolumn{2}{|c|}{ Deltamethrin } & \multicolumn{2}{|c|}{ Deltamethrin } \\
\hline Garoua & $\begin{array}{c}5.3 \\
(4.7-5.9) ; P=0.47\end{array}$ & $\begin{array}{c}11.4 \\
(9.7-14.2) ; P=0.24\end{array}$ & - & - \\
\hline Bertoua & $\begin{array}{c}5.8 \\
(3.3-8.2) ; P=0.46\end{array}$ & $\begin{array}{c}24.6 \\
(16.6-51.4) ; P=0.025\end{array}$ & $\begin{array}{c}7.8 \\
(7.3-8.3) ; P=0.25\end{array}$ & $\begin{array}{c}15.9 \\
(14.4-18.0) ; P=0.38\end{array}$ \\
\hline Yaoundé & $\begin{array}{c}6.7 \\
(3.7-9.7) ; P=0.35\end{array}$ & $\begin{array}{c}22.8 \\
(15.0-58.4) ; P=0.05\end{array}$ & $\begin{array}{c}11.2 \\
(10.6-11.8) ; P=0.06\end{array}$ & $\begin{array}{c}17.3 \\
(16.3-19.0) ; P=0.28\end{array}$ \\
\hline Bafia & $\begin{array}{c}5.4 \\
(3.3-7.4), P=0.48\end{array}$ & $\begin{array}{c}14.6 \\
(10.1-36.9) ; P=0.49\end{array}$ & - & - \\
\hline Buea & - & - & $\begin{array}{c}11.7 \\
(10.2-13.3) ; P=0.06\end{array}$ & $\begin{array}{c}21.2 \\
(18.1-27.4) ; P=0.09\end{array}$ \\
\hline Libreville & $\begin{array}{c}5.9 \\
(5.1-6.8) ; P=0.45\end{array}$ & $\begin{array}{c}13.4 \\
(11.2-17.9) ; P=0.40\end{array}$ & - & - \\
\hline \multirow[t]{2}{*}{ Reference strain } & $\begin{array}{c}5.5 \\
(4.6-6.3)\end{array}$ & $\begin{array}{c}14.5 \\
(11.9-19.4)\end{array}$ & - & - \\
\hline & \multicolumn{2}{|c|}{ DDT } & \multicolumn{2}{|c|}{ DDT } \\
\hline Garoua & $\begin{array}{c}53.6 \\
(49.9-59.2)\end{array}$ & $\begin{array}{c}101.9 \\
(84.0-146.0)\end{array}$ & - & - \\
\hline Bertoua & - & - & $\begin{array}{c}84.8 \\
(72.8-106.9)\end{array}$ & $\begin{array}{c}290.8 \\
(200.7-523.0)\end{array}$ \\
\hline Yaoundé & - & - & $\begin{array}{c}77.4 \\
(68.5-113.2)\end{array}$ & $\begin{array}{c}109.2 \\
(86.1-235.3)\end{array}$ \\
\hline Buea & - & - & $\begin{array}{c}68.0 \\
(63.6-78.2)\end{array}$ & $\begin{array}{c}93.9 \\
(80.7-131.9)\end{array}$ \\
\hline Libreville & $\begin{array}{c}58.7 \\
(55.8-62.7)\end{array}$ & $\begin{array}{c}107.7 \\
(94.6-129.2)\end{array}$ & - & - \\
\hline
\end{tabular}

KdT: Knockdown times expressed in minutes; $95 \% \mathrm{Cl}$ : $95 \%$ confidence interval. *: $\mathrm{P}$ is the probability of homogeneity between the sample and the reference (Mantel-Haenszel chi square). 
called $K d r$ mutation) $[39,44]$. Pyrethroid resistance has also been linked to an increase in metabolic process through over-transcription of detoxification genes [21]. Although the number of studies reporting insecticide resistance in Ae. albopictus has increased this decade $[17,41,42,45,46]$, few have shown evidence of pyrethroid resistance [14]. The $K d r$ mutation has been found in $A e$. aegypti $[39,16]$ but has never been reported in Ae. albopictus. Further molecular and biochemical studies are needed to identify the genetic basis of pyrethroid resistance in Ae. albopictus in Yaoundé. The absence of cross-resistance between DDT and deltamethrin in all mosquito populations (except Ae. albopictus collected in Yaoundé) suggests the involvement of metabolic resistance rather than a target site modification $(K d r$ mutation) in the sodium channel. It is unclear whether cross-resistance to deltamethrin and DDT in the Ae. albopictus population in Yaoundé is due to common or different resistance mechanisms.

The source of DDT and deltamethrin resistance observed here in DENV and CHIKV vectors is unclear. Indeed, in Central Africa, insecticide treatment specifically targeting Ae. aegypti or Ae. albopictus is extremely limited. It is possible that insecticides used to control other insects of medical or agricultural interest exert indirect selection pressure on these two mosquito species. For example, indoor residual spraying of DDT for malaria control [47] was suspected of favouring the selection of DDT resistance in Anopheles [48] as well as in Aedes $[42,45]$. Contamination of larval breeding places by insecticides used in agriculture (cotton, vegetables) has also been shown to select for DDT and pyrethroid resistance in malaria vectors [48-52]. Concerning Ae. albopictus, which recently spread to Cameroon [8], one cannot exclude the possibility that the invading population possessed a resistance background.

\section{Conclusion}

This is the first study of the susceptibility status of $A e$. aegypti and Ae. albopictus to various insecticides in Central Africa. The increase in dengue and chikungunya outbreaks in this region calls for more robust surveillance and vector control. Our observations could help to guide insecticide-based strategies, although broader monitoring of insecticide resistance in Aedes mosquitoes is needed. Further molecular and biochemical studies are also needed to determine the mechanisms involved in insecticide resistance among arboviruses vectors in Central Africa.

\section{Acknowledgements}

We thank Philippe Bousses for significant help with mosquito sampling. This research was supported by the French government through Agence Nationale pour la Recherche that funded the Epidengue project (ANR 05 SEST 010-01). Basile Kamgang is supported by an IRD/DSF PhD fellowship.

\section{Author details}

${ }^{1}$ Institut de Recherche pour le Développement (IRD), UMR 224 MIVEGEC, BP 64501, 34394 Montpellier, France. ' Laboratoire de Recherche sur le Paludisme, Organisation de Coordination pour la lutte contre les Endémies en Afrique Centrale (OCEAC), BP 288, Yaoundé, Cameroun. ${ }^{3}$ Centre de Recherche Entomologique de Cotonou (CREC), BP 2604 Cotonou, République du Bénin. ${ }^{4}$ Centre International de Recherches Médicales de Franceville (CIRMF), BP 769, Franceville, Gabon.

\section{Authors' contributions}

BK and CP designed the study and monitored its implementation. BK, EN and CP participated to field sampling. BK, EN, PN carried out bioassay tests, under guidance of JE. BK, SM and CP analyzed the data. BK, SM, VC and CP wrote the manuscript which was critically revised by FC. All authors read and approved the final manuscript.

\section{Competing interests}

The authors declare that they have no competing interests.

Received: 18 February 2011 Accepted: 15 May 2011

Published: 15 May 2011

\section{References}

1. DJ Gubler, Epidemic dengue/dengue hemorrhagic fever as a public health, social and economic problem in the 21st century. Trends Microbiol. 10, 100-103 (2002). doi:10.1016/S0966-842X(01)02288-0

2. C Peyrefitte, D Rousset, B Pastorino, R Pouillot, M Bessaud, F Tock, H Mansaray, O Merle, A Pascual, C Paupy, A Vessiere, P Imbert, P Tchendjou, JP Durand, H Tolou, M Grandadam, Chikungunya virus, Cameroon 2006. Emerg Infect Dis. 13, 768-771 (2007)

3. R Krippner, $G$ von Laer, First confirmed dengue-1 fever cases reported from Cameroon. J Travel Med. 9, 273-274 (2002)

4. EM Leroy, D Nkoghe, B Ollomo, C Nze-Nkogue, P Becquart, G Grard, X Pourrut, R Charrel, G Moureau, A Ndjoyi-Mbiguino, X De Lamballerie, Concurrent Chikungunya and Dengue Virus Infections during Simultaneous Outbreaks, Gabon, 2007. Emerg Inf Dis. 15, 591-593 (2009). doi:10.3201/ eid1504.080664

5. L Franco, A Di Caro, F Carletti, O Vapalahti, C Renaudat, H Zeller, A Tenorio, Recent expansion of dengue virus serotype 3 in West Africa. Euro Surveill. $15,19490(2010)$

6. M Diallo, J Thonnon, M Traore-Lamizana, D Fontenille, Vectors of Chikungunya virus in Senegal: current data and transmission cycles. Am J Trop Med Hyg. 60, 281-286 (1999)

7. CY Kow, LL Koon, FY Pang, Detection of dengue viruses in field caught male Aedes aegypti and Aedes albopictus (Diptera: Culicidae) in Singapore by type-specific PCR. J Med Entomol. 38, 475-479 (2001). doi:10.1603/00222585-38.4.475

8. C Paupy, H Delatte, L Bagny, V Corbel, D Fontenille, Aedes albopictus, an arbovirus vector: from the darkness to the light. Microbes Infect. 11, 1177-1185 (2009). doi:10.1016/j.micinf.2009.05.005

9. B Kamgang, J Youta Happi, P Boisier, F Njiokou, JP Hervé, F Simard, C Paupy, Geographic and ecological distribution of dengue and chikungunya virus vectors, Aedes aegypti and Aedes albopictus, in urban environments of Cameroon (Central Africa). Med Vet Ent. 24, 132-141 (2010)

10. C Paupy, B Ollomo, B Kamgang, S Moutailler, D Rousset, M Demanou, JP Hervé, EM Leroy, F Simard, Role of Ae. albopictus versus Ae. aegypti in dengue and chikungunya emergences in Central Africa: Laboratory and field evidence. Vector Borne Zoonotic Dis. 10, 259-266 (2010). doi:10.1089/ vbz.2009.0005

11. WHO, Report of the Scientific Working Group on dengue. (Document WHO/TDR/SWG/08, Geneva, Switzerland, World Health Organization, 2006)

12. WHO, Dengue Haemorrhagic Fever: Diagnosis, Treatment, Prevention and Control. (WHO, Geneva, 1997), 2, pp. 1-84

13. R Yaicharoen, R Kiatfuengfoo, $T$ Chaeronviriyaphap, $P$ Rongnoparut, Characterization of deltamethrin, resistance in field populations of Aedes aegyptiin Thailand. J Vect Ecol. 30, 144-150 (2005)

14. A Ponlawat, JG Scott, LC Harrington, Insecticide susceptibility of Aedes aegypti and Aedes albopictus across Thailand. J Med Entomol. 42, 821-825 (2005). doi:10.1603/0022-2585(2005)042[0821:ISOAAA]2.0.CO;2

15. H Ranson, J Burhani, N Lumjuan, WC Black, Insecticide resistance in dengue vectors. TroplKA net Journal. 1(1) (2010) 
16. S Marcombe, A Carron, F Darriet, M Etienne, P Agnew, M Tolosa, MM YpTcha, C Lagneau, A Yébakima, V Corbel, Reduced Efficacy of Pyrethroid Space Sprays for Dengue Control in an Area of Martinique with Pyrethroid Resistance. Am J Trop Med Hyg. 80, 745-751 (2009)

17. N Jirakanjanakit, P Rongnoparut, S Saengtharatip, T Chareonviriyaphap, S Duchon, C Bellec, S Yoksan, Insecticide susceptible/resistance status in Aedes (Stegomyia) aegypti and Aedes (Stegomyia) albopictus (Diptera: Culicidae) in Thailand during 2003-2005. J Econ Entomol. 100, 545-550 (2007). doi:10.1603/0022-0493(2007)100[545:IRSIAS]2.0.CO;2

18. N Jirakanjanakit, S Saengtharatip, P Rongnoparut, S Duchon, C Bellec, S Yoksan, Trend of Temephos resistance in Aedes (Stegomyia) mosquitoes in Thailand during 2003-2005. Environ Entomol. 36, 506-511 (2007). doi:10.1603/0046-225X(2007)36[506:TOTRIA]2.0.CO;2

19. SC Rawlins, R Martinez, S Wiltshire, G Legall, A comparison of surveillance systems for the dengue vector Aedes aegypti in Port of Spain, Trinidad. J Am Mosq Control Assoc. 14, 131-136 (1998)

20. MM Rodriguez, JA Bisset, Y De Armas, F Ramos, Pyrethroid insecticideresistant strain of Aedes aegypti from Cuba induced by deltamethrin selection. J Am Mosq Control Assoc. 21, 437-445 (2005). doi:10.2987/8756971X(2006)21[437:PISOAA]2.0.CO;2

21. S Marcombe, R Poupardin, F Darriet, S Reynaud, J Bonnet, C Strode, C Brengues, A Yébakima, H Ranson, V Corbel, JP David, Exploring the molecular basis of insecticide resistance in the dengue vector Aedes aegypti: a case study in Martinique Island (French West Indies). BMC Genomics. 10, 494 (2009). doi:10.1186/1471-2164-10-494

22. J Hemingway, NJ Hawkes, L McCarroll, H Ranson, The molecular basis of insecticide resistance in mosquitoes. Insect Biochem Mol Biol. 34, 653-665 (2004). doi:10.1016/j.ibmb.2004.03.018

23. J Mouchet, V Cordellier, M Germain, P Carnevale, J Barathe, C Sannier, Résistance aux insecticides d'Aedes aegypti et Culex pipiens fatigans en Afrique centrale. (WHO/NBC/72/381, 12P, Geneva, Switzerland, World Health Organization, 1972)

24. WHO, Guidelines for laboratory and field testing of mosquito larvicides. (Document WHO/CDS/WHOPES/GCDPP/13, Geneva, Switzerland, World Health Organization, 2005)

25. WHO, Guidelines for testing mosquito adulticides for indoor residual spraying and treatment of mosquito nets. (Document WHO/CDS/NTD/ WHOPES/GCDPP/3, Geneva, Switzerland, World Health Organization, 2006)

26. M Giner, C Vassal, Z Kouaik, F Chiroleu, JM Vassal, Win DL version 2.0. (Paris: CIRAD-CA, U.R.B.I/M.A.B.I.S, 1999)

27. WHO, Test Procedures for insecticide resistance monitoring in malaria vectors, bio-efficacy and persistence of insecticide on treated surfaces (Document WHO/CDS/CPC/MAL/98.12, Geneva, Switzerland, World Health Organization, 1998)

28. A Paul, LC Harrington, L Zhang, JG Scott, Insecticide resistance in Culex pipiens from New York. J Am Mosq Control Assoc. 21, 305-309 (2005). doi:10.2987/8756-971X(2005)21[305:IRICPF]2.0.CO;2

29. M Paris, G Tetreau, F Laurent, M Lelu, L Despres, JP David, Persistence of Bacillus thuringiensis israelensis (Bti) in the environment induces resistance to multiple Bti toxins in mosquitoes. Pest Manag Sci. 67, 122-128 (2011). doi:10.1002/ps.2046

30. HL Lee, W Lime, A reevaluation of the susceptibility of field collected Aedes (Stegomyia) aegypti (Linnaeus) larvae to temephos in Malaysia. MosquitoBorne Dis Bull. 6, 91-95 (1989)

31. T Chareonviriyaphap, B Aum-aung, S Ratanatham, Current insecticide resistance pattern in mosquito vectors in Thailand. Southeast Asian J Trop Med Public Health. 30, 184-194 (1999)

32. P Paeporn, N Komalamisra, V Deesin, Y Rongsriyam, Y Eshita, S Thongrungkiat, Temephos resistance in two forms of Aedes aegypti and its significance for the resistance mechanism. Southeast Asian J Trop Med Public Health. 34, 786-792 (2003)

33. KA Polson, C Curtis, MS Chang, JG Olson, N Chantha, SC Rawlins, Susceptibility of two Cambodian population of Aedes aegypti mosquito larvae to temephos during 2001. Dengue Bull. 25, 79-83 (2001)

34. CD Chen, WA Nazni, HL Lee, M Sofian-Azirun, Susceptibility of Aedes aegypti and Aedes albopictus to temephos in four study sites in Kuala Lumpur City Center and Selangor State, Malaysia. Trop Biomed. 22, 207-216 (2005)

35. MLG Macoris, MTM Andrighetti, V Takaku, CM Glasser, VC Garbeloto, JE Bracco, Resistance of Aedes aegypti from the state of Sao Paulo, Brazil to organophosphates insecticides. Mem Inst Oswaldo Cruz. 98, 703-708 (2003). doi:10.1590/S0074-02762003000500020
36. GA Llinás, E Seccacini, CN Gardenal, S Licastro, Current resistance status to temephos in Aedes aegypti from different regions of Argentina. Mem Inst Oswaldo Cruz. 105, 113-116 (2010). doi:10.1590/S0074-02762010000100019

37. MA Melo-Santos, Jj Varjal-Melo, AP Araújo, TC Gomes, MH Paiva, LN Regis, AF Furtado, T Magalhaes, ML Macoris, MT Andrighetti, CF Ayres, Resistance to the organophosphate temephos: mechanisms, evolution and reversion in an Aedes aegypti laboratory strain from Brazil. Acta Trop. 113, 180-189 (2010). doi:10.1016/j.actatropica.2009.10.015

38. WA Nazni, MY Kamaludin, HL Lee, TAR Rogayah, I Sa'diyah, Oxidase activity in relation to insecticides resitance in vectors of public health importance. Trop Biomed. 17, 69-79 (2000)

39. C Brengues, NJ Hawkes, F Chandre, L McCarroll, S Duchon, P Guillet, S Manguin, JC Morgan, J Hemingway, Pyrethroids and DDT cross-resistance in Aedes aegypti is correlated with novel mutations in the voltage-gated sodium channel gene. Med Vet Entomol. 17, 87-94 (2003). doi:10.1046/ j.1365-2915.2003.00412.x

40. N Lumjuan, L McCarroll, LA Prapanthadara, J Hemingway, H Ranson, Elevated activity of an Epsilon class glutathione transferase confers DDT resistance in the dengue vector, Aedes aegypti. Insect Biochem Mol Biol. 35, 861-871 (2005). doi:10.1016/j.ibmb.2005.03.008

41. P Somboon, LA Prapanthadara, W Suwonkerd, Insecticide susceptibility tests of Anopheles minimus s.l., Aedes aegypti, Aedes albopictus, and Culex quinquefasciatus in northern Thailand. Southeast Asian J Trop Med Public Health. 34, 87-93 (2003)

42. H Kawada, Y Maekawa, M Abe, K Ohashi, SY Ohba, M Takagi, Spatial distribution and pyrethroid susceptibility of mosquito larvae collected from catch basins in parks in Nagasaki city, Nagasaki, Japan. Jpn J Infect Dis. 63, 19-24 (2010)

43. J Hemingway, $H$ Ranson, Insecticide in insect vectors of human diseases. Annu Rev Entomol. 45, 371-391 (2000). doi:10.1146/annurev.ento.45.1.371

44. K Saavedra-Rodriguez, L Urdaneta-Marquez, S Rajatileka, M Moulton, AE Flores, I Fernandez-Salas, J Bisset, M Rodriguez, PJ McCall, MJ Donnelly, H Ranson, J Hemingway, WC Black IV, A mutation in the voltage-gated sodium channel gene associated with pyrethroid resistance in Latin American Aedes aegypti. Insect Mol Biol. 16, 785-798 (2007). doi:10.1111/ j.1365-2583.2007.00774.x

45. LT Ping, R Yatiman, LP Gek, Susceptibility of adult field strains of Aedes aegypti and Aedes albopictus in Singapore to pirimiphos-methyl and permethrin. J Am Mosq Control Assoc. 17, 144-146 (2001)

46. R Romi, L Toma, F Severini, M Di Luca, Susceptibility of Italian populations of Aedes albopictus to Temephos and to other insecticides. J Am Mosq Control Assoc. 19, 419-423 (2003)

47. CF Curtis, AE Mnzava, Comparison of house spraying and insecticidetreated nets for malaria control. Bull World Health Organ. 78, 1389-1400 (2000)

48. V Corbel, R N'Guessan, C Brengues, F Chandre, L Djogbenou, T Martin, M Akogbéto, JM Hougard, M Rowland, Multiple insecticide resistance mechanisms in Anopheles gambiae and Culex quinquefasciatus from Benin, West Africa. Acta Trop. 101, 207-216 (2007). doi:10.1016/j. actatropica.2007.01.005

49. RF Djouaka, AA Bakare, ON Coulibaly, MC Akogbeto, H Ranson, J Hemingway, C Strode, Expression of the cytochrome P450s, CYP6P3 and CYP6M2 are significantly elevated in multiple pyrethroid resistant populations of Anopheles gambiae s.s. from Southern Benin and Nigeria. BMC Genomics. 13, 538 (2008)

50. F Chandre, F Darriet, L Manga, M Akogbeto, O Faye, J Mouchet, P Guillet, Status of pyrethroid resistance in Anopheles gambiae sensu lato. Bull World Health Organ. 77, 230-234 (1999)

51. A Diabate, T Baldet, F Chandre, M Akogbeto, TR Guiguemde, F Darriet, C Brengues, P Guillet, I Hemingway, GJ Small, JM Hougard, The role of agricultural use of insecticides in resistance to pyrethroids in Anopheles gambiae s.l. in Burkina Faso. Am J Trop Med Hyg. 67, 617-622 (2002)

52. A Yadouleton, $T$ Martin, G Padonou, F Chandre, A Asidi, L Djogbenou, $R$ Dabiré, R Aikpon, M Boko, I Glitho, M Akogbeto, Cotton pest management practices and the selection of pyrethroid resistance in Anopheles gambiae population in Northern Benin. Parasit Vectors. 4, 60 (2011). doi:10.1186/ 1756-3305-4-60

doi:10.1186/1756-3305-4-79

Cite this article as: Kamgang et al:: Insecticide susceptibility of Aedes aegypti and Aedes albopictus in Central Africa. Parasites \& Vectors 2011 4:79. 